\title{
CARLSBAD AREA OFFICE VEHICLE SAFETY PROGRAM
}
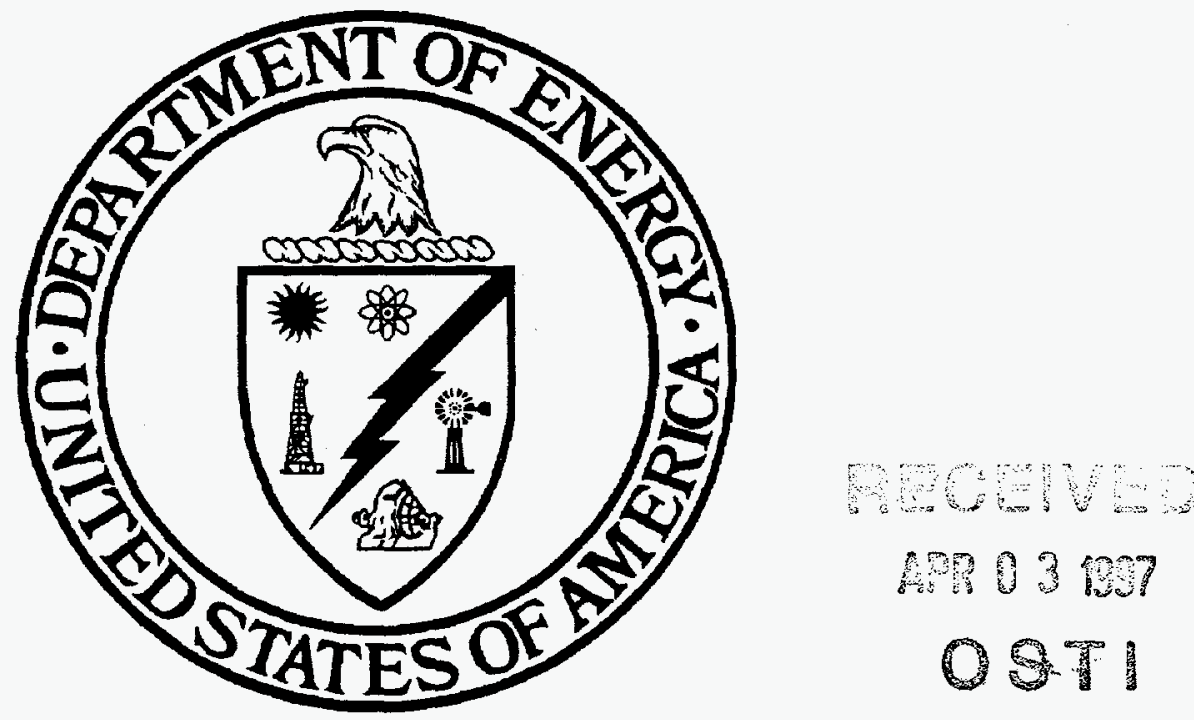

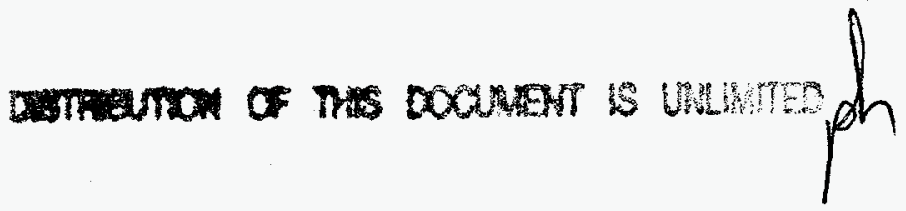

December 1996

Submitted by:

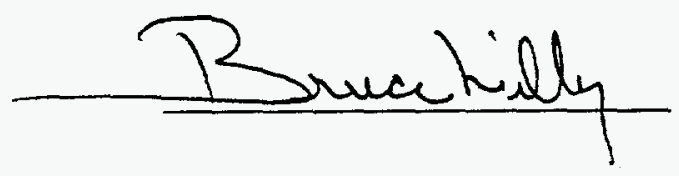

L. Bruce Lilly, Manager

Safety and Occupational Health
Approved by:

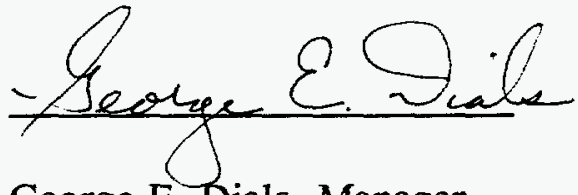

George E. Dials, Manager Carlsbad Area Office

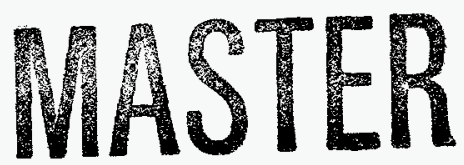




\section{DISCLAIMIER}

Portions of this document may be illegible in electronic image products. Images are produced from the best available original document. 


\section{DISCLAIMER}

This report was prepared as an account of work sponsored by an agency of the United States Government. Neither the United States Government nor any agency thereof, nor any of their employees, make any warranty, express or implied, or assumes any legal liability or responsibility for the accuracy, completeness, or usefulness of any information, apparatus, product, or process disclosed, or represents that its use would not infringe privately owned rights. Reference herein to any specific commercial product, process, or service by trade name, trademark, manufacturer, or otherwise does not necessarily constitute or imply its endorsement, recommendation, or favoring by the United States Government or any agency thereof. The views and opinions of authors expressed herein do not necessarily state or reflect those of the United States Government or any agency thereof. 
This document has been reproduced directly from the best possible copy.

It is available to DOE and DOE contractors at the following addresses:

Office of Scientific and Technical Information

P.O. Box 62

Oak Ridge, TN 37831

Prices available from (615) 576-8401

Available to the public from the National Technical Information Services

U. S. Department of Commerce 5285 Port Royal Road

Springfield, VA 22161

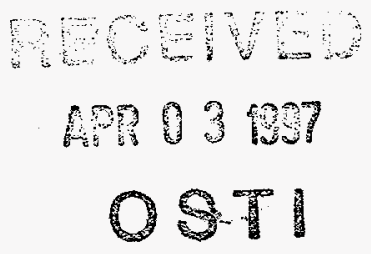

Processing and final preparation of this report was performed by the Waste Isolation Pilot Plant Management and Operating Contractor for the U.S. Department of Energy under Contract No. DE-ACO4-86AL31950. 


\section{TABLE OF CONTENTS}

1.0 INTRODUCTION AND OBJECTIVES $\ldots \ldots \ldots \ldots \ldots \ldots \ldots \ldots \ldots$

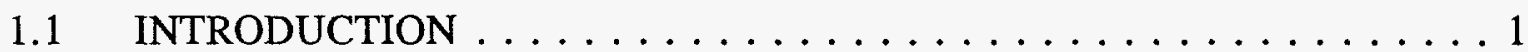

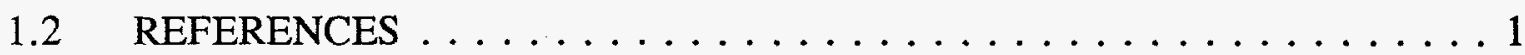

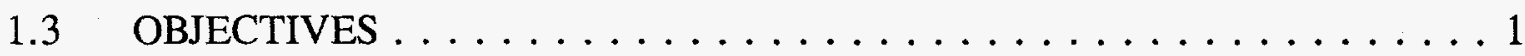

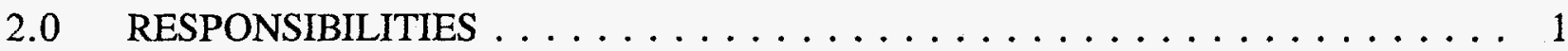

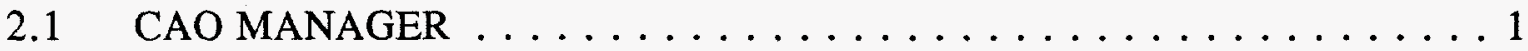

2.2 CAO SAFETY AND OCCUPATIONAL HEALTH MANAGER $\ldots \ldots \ldots 2$

2.3 CAO TEAM LEADERS AND ASSISTANT MANAGERS $\ldots \ldots \ldots \ldots .2$

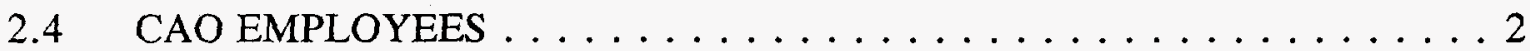

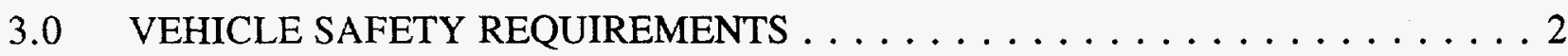

3.1 DRIVER QUALIFICATIONS, LICENSING, AND RECORDS . . . . . 2

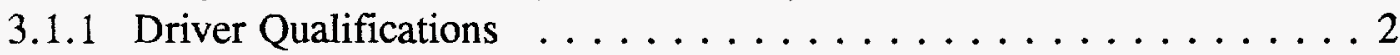

3.1 .2 Records . . . . . . . . . . . . . . . . 3

3.2 SUSPENSION OF OFFICIAL OPERATOR'S LICENSE $\ldots \ldots \ldots \ldots \ldots 3$

3.3 DRIVER TRAINING . . . . . . . . . . . . . . 3

3.4 VEHICLE INSPECTION AND MAINTENANCE $\ldots \ldots \ldots \ldots \ldots 3$

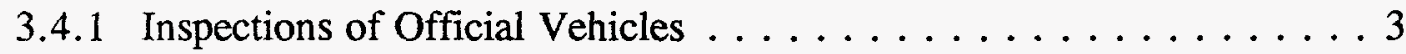

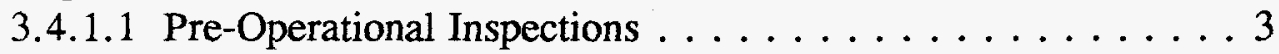

3.4.1.2 Periodic Inspections $\ldots \ldots \ldots \ldots \ldots \ldots$

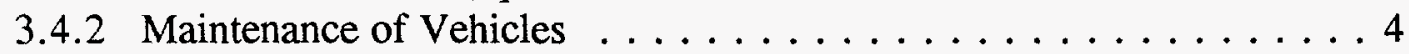

3.5 ACCIDENT REPORTING AND INVESTIGATIONS $\ldots \ldots \ldots \ldots \ldots 4$

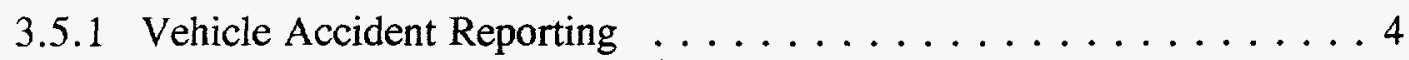

3.5.2 Vehicle Accident/Incident Investigation. . . . . . . . . 4

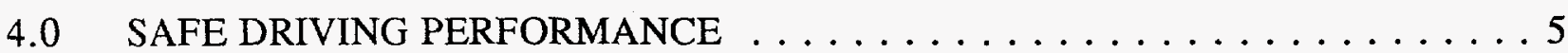

4.1 GENERAL DRIVING RULES $\ldots \ldots \ldots \ldots \ldots \ldots \ldots \ldots \ldots \ldots$

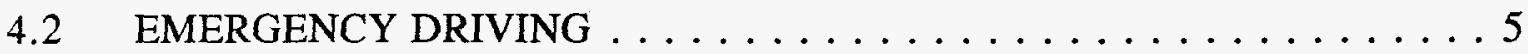

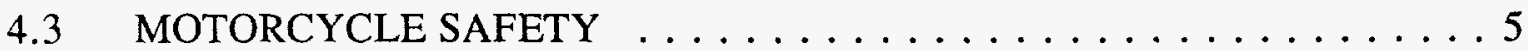

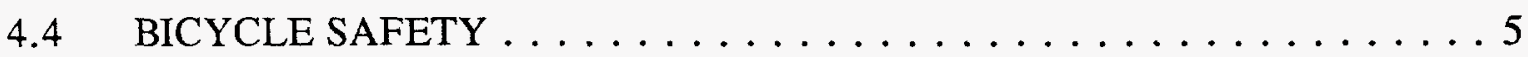

4.5 PEDESTRIAN SAFETY $\ldots \ldots \ldots \ldots \ldots \ldots \ldots \ldots \ldots \ldots \ldots \ldots$

4.6 SPECIAL PURPOSE VEHICLE SAFETY $\ldots \ldots \ldots \ldots \ldots$

4.6.1 All Terrain Vehicle (ATV) Safety $\ldots \ldots \ldots \ldots \ldots \ldots \ldots$

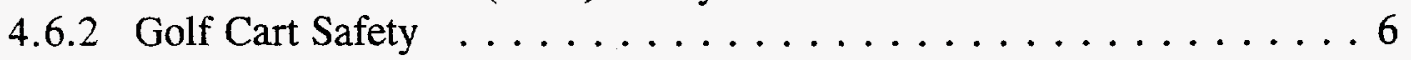

4.7 OFF-THE-JOB DRIVING SAFETY $\ldots \ldots \ldots \ldots \ldots \ldots \ldots$ 
TABLE OF CONTENTS

(CONTINUED)

SECTION

PAGE

5.0 TRAFFIC AND PARKING CONTROL $\ldots \ldots \ldots \ldots \ldots \ldots \ldots \ldots \ldots \ldots$

5.1 TRAFFIC CONTROLS $\ldots \ldots \ldots \ldots \ldots \ldots \ldots \ldots \ldots \ldots \ldots$

5.2 PARKING CONTROLS $\ldots \ldots \ldots \ldots \ldots \ldots \ldots \ldots \ldots$

6.0 VEHICLE SAFETY COMMUNICATIONS $\ldots \ldots \ldots \ldots \ldots \ldots \ldots$

6.1 FEDERAL EMPLOYEE SAFETY COMMITTEE MEETINGS $\ldots \ldots \ldots 7$

6.2 HOLIDAY SAFETY $\ldots \ldots \ldots \ldots \ldots \ldots \ldots \ldots \ldots$

6.3 VEHICLE SAFETY INFORMATION $\ldots \ldots \ldots \ldots \ldots \ldots \ldots \ldots 7$

6.4 VEHICLE SAFETY SUGGESTIONS $\ldots \ldots \ldots \ldots \ldots \ldots$

ATTACHMENT 1: Motor Vehicle Accident Report (Standard Form 91)

ATTACHMENT 2: Statement of Witness (Standard Form 94)

Processing and final preparation of this report was performed by the Waste Isolation Pilot Plant Management and Operating Contractor for the U.S. Department of Energy under Contract No. DE-ACO4-86AL31950. 


\subsection{INTRODUCTION AND OBJECTIVES}

\subsection{INTRODUCTION}

The Carlsbad Area Office (CAO) Vehicle Safety Program (VSP) establishes the minimum requirements for CAO personnel to safely operate government vehicles and provides direction to effectively reduce the number of vehicle accidents, reduce the severity of vehicle accidents, and minimize vehicular property damage. This Program covers the operations of Government Services Administration (GSA) vehicles, rental or leased vehicles, and special purpose vehicles used at the Waste Isolation Pilot Plant (WIPP) in the performance of work. Additionally, this Program encourages CAO employees to use safe driving habits while operating their privately owned vehicles, motorcycles, or bicycles, or, as pedestrians, to be aware of the hazards associated with traffic in and around CAO facilities.

Vehicle safety is a shared responsibility in this organization. At anytime a CAO employee witnesses an unsafe act relating to the operation of a motor vehicle, it is their responsibility to notify their Team Leader (TL) or Assistant Manager (AM), or contact the CAO Safety and Occupational Health Manager (SOHM). Employees are encouraged to participate in the Carlsbad Area Office Federal Employees Safety Committee (FESC) activities and goals in order to address vehicle safety concerns. The FESC is designed to be a forum for all federal employees to improve the health and safety of our organization.

The VSP is an effective method of ensuring the health and safety of CAO employees during the operation of government vehicles. The human resources of the CAO are the most valuable assets of this organization and any lost manhours are difficult to replace. Safe driving habits and defensive driving methods should always be practiced to preserve the health and safety of all employees.

\subsection{REFERENCES}

- DOE Order O 440.1, Federal Employee Occupational Safety and Health Program

- DOE Order 3791.2A, Federal Employee Motor Vehicle Safety Program

- DOE Order O 232.1, Occurrence Reporting and Processing of Operations Information.

\subsection{OBJECTIVES}

The major objectives of the VSP are to:

- Reduce vehicular accidents, personnel injuries, and property damage

- Train new CAO employees in defensive driving and accident prevention.

\subsection{RESPONSIBILITIES}

\subsection{CAO MANAGER}

Overall authority for the development and implementation of the CAO Vehicle Safety Program belongs to the CAO Manager. The CAO Manager is responsible for approving this document. Responsibility for the execution of the VSP, which includes effective implementation, is delegated to the CAO SOHM. 


\subsection{CAO SAFETY AND OCCUPATIONAL HEALTH MANAGER}

The CAO SOHM shall ensure that only authorized employees operate government vehicles. He shall ensure each driver is properly licensed and trained within the scope of this program. He shall maintain all appropriate records and documentation associated with the VSP, and provide statistical information to management, such as, but not limited to, monthly accident reports, accident trending, cost factors associated to vehicle accidents, etc.

\subsection{CAO TEAM LEADERS AND ASSISTANT MANAGERS}

TLs and AMs shall ensure that government vehicles under their responsibility are inspected on a regular basis. Safety reviews and periodic inspections of the vehicles will be conducted to ensure that the vehicles meet safety standards. Also reviews will be conducted to verify that operators are properly licensed, and that vehicles are used for official business only. Detailed safety inspections, as deemed necessary by the cognizant maintenance organization and authorized by the GSA, will be performed on a periodic basis by qualified service organizations.

\subsection{CAO EMPLOYEES}

All employees shall have authorization before operating a government vehicle. They shall report all vehicle accidents, unsafe vehicles, and unsafe driving behavior to their TLs or AMs. They shall operate vehicles in a safe and responsible manner, protect government property, and make every effort to prevent vehicle accidents.

\subsection{VEHICLE SAFETY REQUIREMENTS}

\subsection{DRIVER QUALIFICATIONS, LICENSING, AND RECORDS}

\subsubsection{Driver Qualifications}

CAO employees operating a government vehicle shall possess a valid state driver's license, be physically qualified, and have a safe driving record.

Two operating levels are defined in DOE Order 3791.2A. These levels are classified as an "operator" defined as "an employee who is regularly required to operate motor vehicles and whose position is classified officially as a motor vehicle operator" and "incidental operator" defined as "any employee other than an operator, who occasionally operates a motor vehicle to carry out assigned duties." As clarified in a February 26, 1995 memorandum (OSHD:JRB (94-201)) from the Director of the Occupational Safety and Health Division of the Department of Energy Albuquerque Operations Office, only individuals identified as "operators" are required to have government driver's licenses. Individuals identified as "incidental operators" are not required to have government driver's licenses. 


\subsubsection{Records}

All vehicle accident reports, unsafe driving reports, and associated vehicle safety documentation shall be maintained by the CAO SOHM.

\subsection{SUSPENSION OF OFFICIAL OPERATOR'S LICENSE}

The right to operate a government vehicle shall be suspended for any of the following reasons:

- Operating a vehicle while under the influence of alcohol

- Operating a vehicle while in possession of or under the influence of a controlled substance

- Leaving the scene of a vehicle or pedestrian accident

- Committing a felony involving the use of a vehicle

- Revocation of the state driver's license

- Reckless driving.

The final decision for suspension rests with the CAO Manager and is based on the recommendation of the CAO SOHM. The decision to suspend the right to operate a government vehicle shall be documented with cause and maintained by the CAO SOHM.

\subsection{DRIVER TRAINING}

Initial training for newly authorized incidental government vehicle operators shall include:

- Operator's Report of Motor Vehicle Accident (Form 91)

- Accident Reporting Procedures

- Use of seat belts

- Safety features of government vehicles

- $\quad$ Effects of alcohol and drugs on driving

- Defensive driving within ninety (90) days of the hiring date

- Local driving hazards.

Additional training will be provided for those employees who require the use of special purpose vehicles (such as, golf carts) in their conduct of work. Refresher defensive driving shall be provided to operators involved in a government vehicle accident or every three years.

\subsection{VEHICLE INSPECTION AND MAINTENANCE}

\subsubsection{Inspection of Official Vehicles}

\subsubsection{Pre-Operational Inspections}

Employees operating a government vehicle will inspect that vehicle prior to the operation of the vehicle each day of use. These inspections will be documented only if there are deficiencies. If during the course of operation there is a deficiency noticed, it will be noted on the inspection form 
and submitted to the TL or AM and appropriate maintenance personnel. Operators will inspect for the serviceability of the following:

$\begin{array}{ll}- & \text { Service Brakes } \\ - & \text { Steering } \\ - & \text { Tires } \\ -\quad \text { Horn } \\ -\quad \text { Seat Belts }\end{array}$

$$
\begin{array}{ll}
- & \text { Parking Brake } \\
- & \text { Lights } \\
- & \text { Fluid Levels } \\
- & \text { Rear View Mirrors } \\
& \text { Windshield Wipers. }
\end{array}
$$

The operator will maintain a clean vehicle, especially windshields, rear window, and all mirrors.

\subsubsection{Periodic Inspections}

Periodic inspections will be performed by the appropriate maintenance organization. The CAO SOHM will also conduct inspections to ensure all requirements are met and current. If deficiencies related to safety are noted, the CAO SOHM will document these deficiencies and notify the appropriate maintenance organization. The appropriate maintenance organization will indicate in writing to the CAO SOHM what corrective actions are being taken to prevent any future occurrence of those deficiencies.

\subsubsection{Maintenance of Vehicles}

The maintenance of the government vehicles shall be conducted in accordance with the direction of GSA and the maintenance contractor. Operators are responsible to add oil, transmission fluid, windshield washer fluid, etc., as required. If excess amounts of fluid are required during the course of normal vehicle operation, it should be noted, and the TL or AM and appropriate maintenance organization notified.

\subsection{ACCIDENT REPORTING AND INVESTIGATIONS}

\subsubsection{Vehicle Accident Reporting}

When either government vehicles or a government vehicle and a pedestrian is involved in an accident, the following will be done in order, depending on the severity of the situation:

- Assist the injured

- Notify the authorities (i.e., police, ambulance, fire department, etc.)

- Notify the TL or AM to give information as to the location, result, and cause of the accident

- Complete Motor vehicle Accident Report, Standard Form 91, (Attachment 1). As appropriate, obtain statement of witnesses using the Statement of Witness form, Standard Form 94, (Attachment 2).

\subsubsection{Vehicle Accident/Incident Investigation}

Regardless of the reporting criteria, all accidents/incidents will be investigated by the CAO SOHM. A formal investigation may be required based on the requirements established by DOE Order $\mathrm{O} 232.1$. The result of all investigations will be reviewed by the CAO Manager to determine recommendations to prevent reccurrence or to recommend disciplinary actions. 


\subsection{SAFE DRIVING PERFORMANCE}

\subsection{GENERAL DRIVING RULES}

CAO employees who drive government vehicles are prohibited from driving official vehicles without authorization; prohibited from using official vehicles for personal business; prohibited from consuming any alcoholic beverage and/or using any controlled or illegal drug while driving an official vehicle; and prohibited from using a government vehicle with noted safety deficiencies.

CAO employees who drive government vehicles shall use seat belts properly for all occupants of the vehicle, shall obey all local, state, and federal laws, shall adhere to all posted speed limits, shall reduce speed during periods of inclement weather or exposed to other driving hazards, shall use extreme caution when backing and are encouraged to use ground guides or spoters whenever possible, shall yield to emergency vehicles, shall set the vehicle shift selector in "Park" (if automatic) or "1st" gear (if standard), shall set the vehicle parking brake when parked, shall secure vehicles when parked and left unattended, and shall drive defensively and avoid reckless driving behavior.

\subsection{EMERGENCY DRIVING}

There are no emergency vehicles (i.e., fire trucks, ambulances, etc.) assigned to federal employees in the CAO. Emergency driving will be avoided because of the risk involved to driver, vehicle, and pedestrians. Incidental drivers are not authorized to conduct emergency driving at any time.

\subsection{MOTORCYCLE SAFETY}

CAO employees who drive motorcycles as their privately owned vehicle are encouraged to attend a Motorcycle Safety Course prior to operation of the vehicle. Motorcyclists are encouraged to wear long pants, gloves, sturdy shoes, long sleeve shirts or a heavy jacket, safety helmet with face shield, and a reflective vest.

Motorcyclists are reminded that their vehicle is harder to see during normal driving conditions and should drive with vehicle lights on to become more visible to other traffic.

\subsection{BICYCLE SAFETY}

CAO employees who use bicycles to travel to work or exercise are reminded that they must obey all traffic regulations the same as any licensed vehicle. Bicyclists are encouraged to wear gloves, reflective vests, and approved safety helmets in order to prevent serious injury. 


\subsection{PEDESTRIAN SAFETY}

Pedestrians should always exercise extreme caution while in or around traffic areas. Pedestrians shall cross streets at intersections with designated crosswalks and should use designated walkways. If there are no walkways, then pedestrians should walk on the shoulder of the street facing oncoming traffic.

Employees who jog or walk for exercise are to abide by the pedestrian rules and right-of-way should be yielded to vehicles. Walkers and joggers are encouraged to wear bright colored attire or reflective vests to enhance visibility.

\subsection{SPECIAL PURPOSE VEHICLE SAFETY}

\subsubsection{All Terrain Vehicle (ATV) Safety}

There are no requirements for CAO employees to utilize an ATV. However, if a special situation occurs that requires the use of an ATV, the operator will exercise extreme caution and abide by all manufacturer rules for driving that specific vehicle.

\subsubsection{Golf Cart Safety}

Golf carts pose an additional hazard to vehicle safety because they are not designed to be operated on public streets. Also, the carts may operate quietly, so pedestrians are not aware of the vehicle's presence. Golf cart operators will receive special training in accordance with Section 3.3 of this Plan on the operation of these special vehicles.

\subsection{OFF-THE-JOB DRIVING SAFETY}

CAO employees are encouraged to maintain their personal automobiles and vehicles in good working condition and ensure that all safety equipment is installed and is in operational condition.

To promote energy conservation and reduce traffic density, car and van pools are encouraged when commuting to and from work. Employees traveling to the WIPP Site should exercise caution due to unusual and sometimes hazardous road conditions. Certain roads leading to the WIPP are open range and livestock may roam freely along the road. The traveler must also be prepared for wildlife and heavy commercial vehicular traffic.

\subsection{TRAFFIC AND PARKING CONTROL}

\subsection{TRAFFIC CONTROLS}

CAO employees who drive government vehicles will maintain a safe speed based on road, weather, and traffic conditions, regardless of the posted speed limits. The posted speed limit in parking lots is not to exceed ten (10) miles per hour. 


\subsection{PARKING CONTROLS}

Parking shall be prohibited in fire lanes, near trash dumpsters, fire hydrants, restricted areas inside the WIPP area, adjacent to yellow curbs, and alongside excavations or obstructions.

Van and car pool parking is reserved for those authorized vehicles. Only authorized persons shall be allowed to park in the handicapped parking and reserved parking area. Personal vehicles shall be restricted to designated parking areas only.

\subsection{VEHICLE SAFETY COMMUNICATIONS}

\subsection{FEDERAL EMPLOYEE SAFETY COMMITTEE MEETINGS}

Every other month the Federal Employee Safety Committee meets and will address safety concerns. CAO employees' input during these sessions is strongly encouraged to facilitate an open forum for problem resolution and problem identification associated with vehicle safety.

\subsection{HOLIDAY SAFETY}

TLs and AMs are encouraged to conduct organizational safety briefings prior to long weekends and/or holidays. Topics during these briefings should cover defensive driving, sufficient rest during long driving periods, changing road conditions, well maintained vehicles, and nonconsumption of alcohol or controlled substances while driving. These briefings would be a good forum to address other safety issues, such as boating, swimming, home safety, etc.

\subsection{VEHICLE SAFETY INFORMATION}

Vehicle safety information will be disseminated to the employees either through a safety bulletin or periodical published through the CAO. Topics will include accident experience, vehicle rules, and general vehicle safety for work and non-duty hours.

\subsection{VEHICLE SAFETY SUGGESTIONS}

CAO employees are encouraged to use the safety committee or TL or AM to make suggestions to enhance the VSP. The CAO SOHM will evaluate all suggestions which may be incorporated into the program. 


\section{ATTACHMENT 1}

Motor Vehicle Accident Report (Standard Form 91) 
To be opened ONLY in case of accident.

\section{CONTENTS}

\section{SF91, MOTOR VEHICLE ACCIDENT REPORT} (1 copy)

\section{SF94, STATEMENT OF WITNESS (2 copies)}

\section{PROOF OF INSURANCE}

\section{FOR OPERATORS OF GSA OWNED VEHICLES}

This constitutes your "Proof of Insurance" and should be carried in your vehicle at all times. The U.S. Government is self-insured. No insurance identification number is required.

Claims against the U.S. Government resulting from the operation of a Government vehicle should be directed to the agency employing the driver of the vehicle, not GSA. Claims against other parties for damage to GSA vehicles will be processed by GSA. Drivers are responsible for obtaining the correct insurance information for processing such claims against other responsible parties.

GSA FORM 1627 BACK (REV. 5-94)
GENERAL SERVICES ADMINISTRATION MOTOR VEHICLE ACCIDENT REPORTING KIT

\section{IN CASE OF ACCIDENT}

1. Stop immediately.

2. Take steps to prevent enother accident at the scene.

3. Call a doctor or ambulance if necessery.

4. Notify police.

5. DO NOT sign any paper or make any statement as to who was at fault (except to your supervisor or to a Federal Government investigator.)

6. Get name and address of each witness. Ask the witness to complete Standard Form 94 , Statement of Witness. contained in

7. State your name, address, place of employment name of your supervisor, and upon request show your operator's permit and vehicle registration card. (NOTE: Only Governmentowned or leased vehicles registered in the District of Columbia or displaying state tags have registration cards.)

8. Complete Standard Form 91. Motor Vehicle Accident Report (or reporting form required by your agency) ot the scene. If conditions prevent this, make notes of the following:

a. Registration information for other vehicle(s) lowner's name, teg number and state serial number, and vehicle description);

b. Information on other driver (name address, operator's permit number, and expiration date):

c. Name and address of each person involved and extent of injury, if eny:

d. Name and address of company insuring other vehicle(s) and insurance policy number, and:

e. General information such as location, time measuremente, weather, damage, etc.

9. As soon as possible, notify your supervisor and the manager of the Fleet Management Center listed on the front cover of the

10. If the vehicie is unsafe to operate. call the Fleet Management Center of Maintenance Control Center for instructions. If you are Control Center due to accident occurring ater normal duty hours or on holidays have the vehicle towed to the nearest repoir shop or service station. The Fleet Management Center must ba notified concerning the vehicle's location as soon as possible.

11. Submit all reports and data to your supervisor within one working day.

12. Injuries should be processed through your agency personnel office using a CA-1 form.

NOTE: If you are injured, have the police notify your supervisor who will assume your responsibilities for reporting the accident.

(See list of contents on reverse.) GSAFORM 1627(REV. 5-94)

ATT 1 - 1 


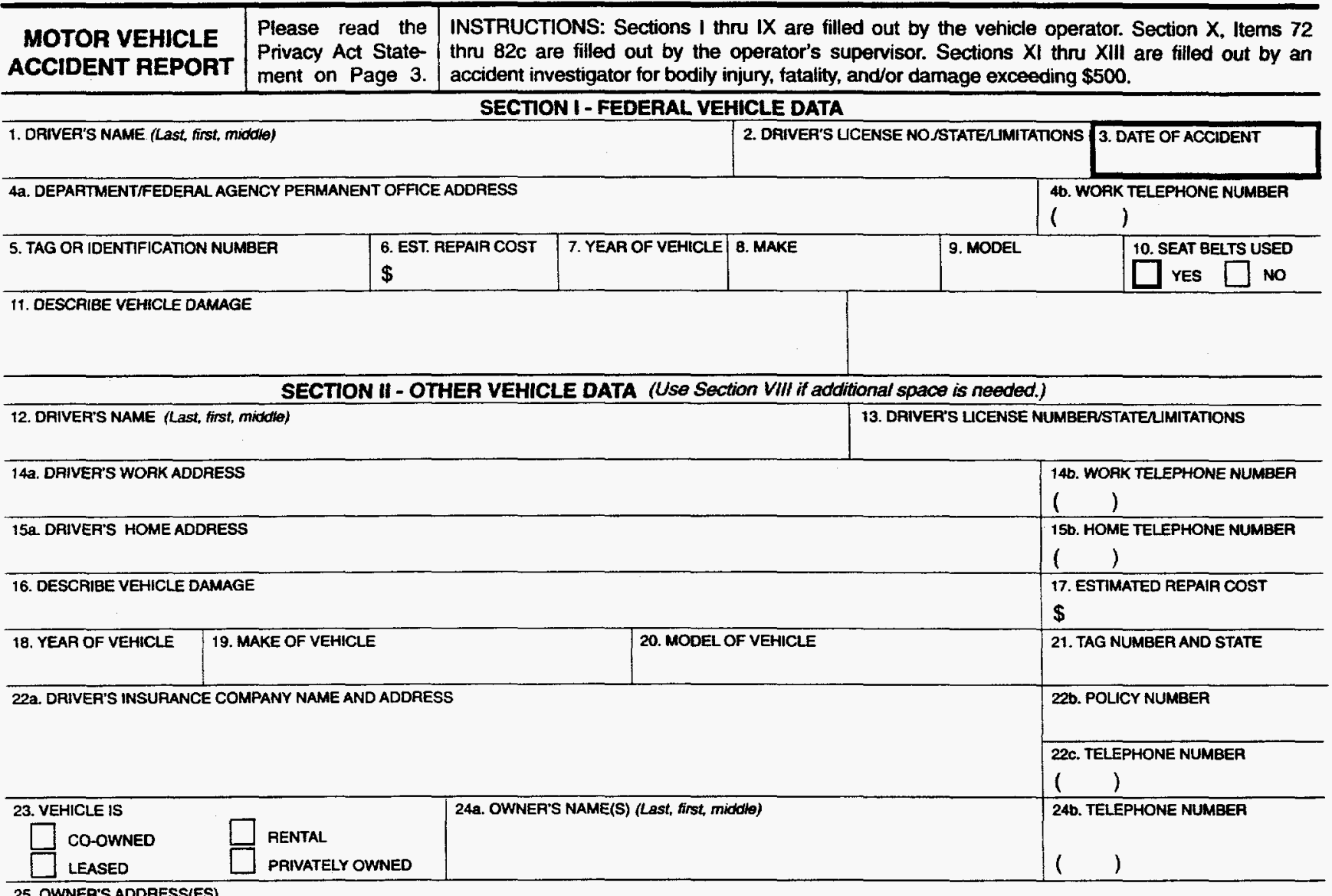

\section{SECTION III - KILLED OR INJURED (Use Section VIII if additional space is needed.)}

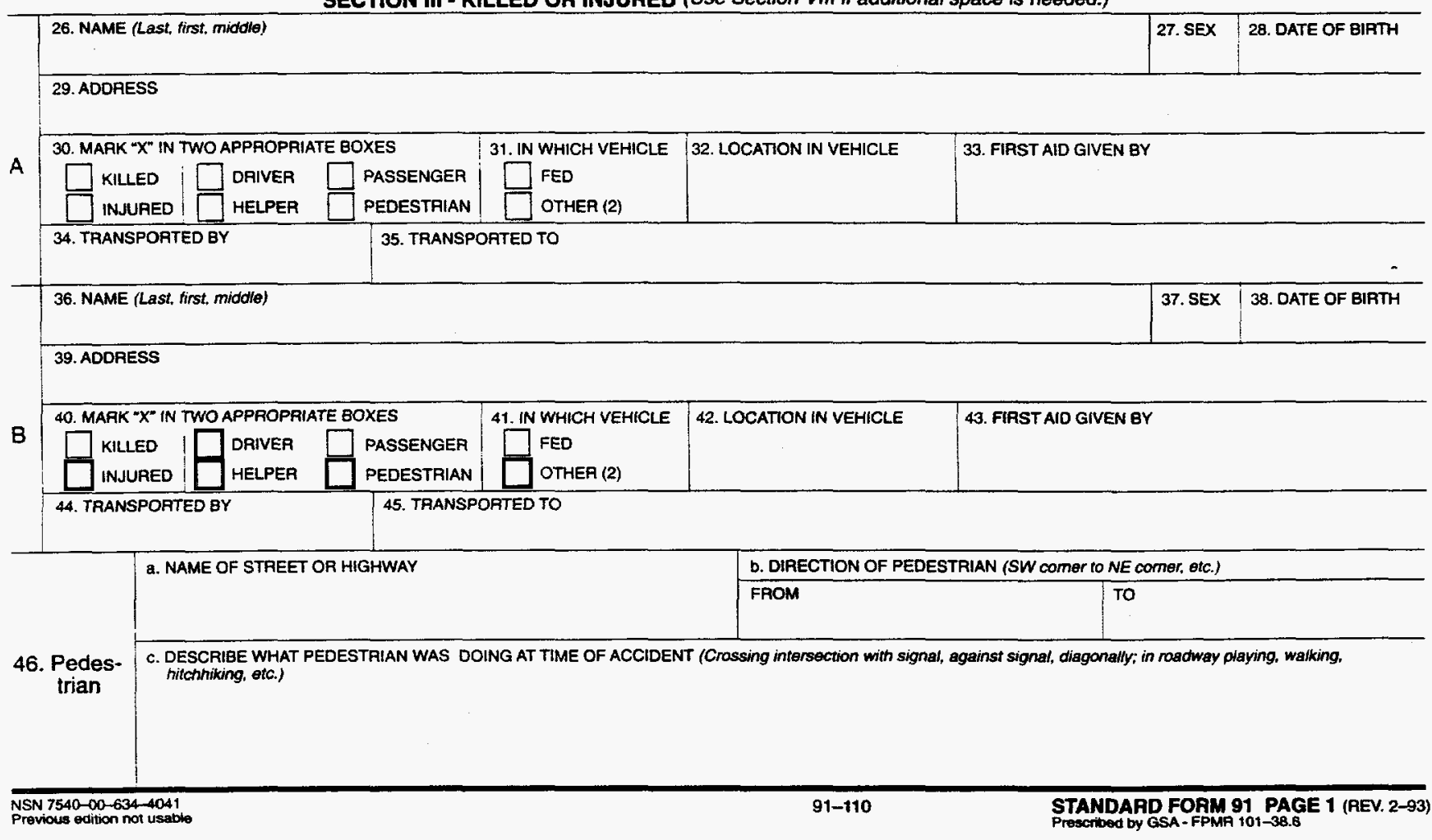

ATT 1 - 2 


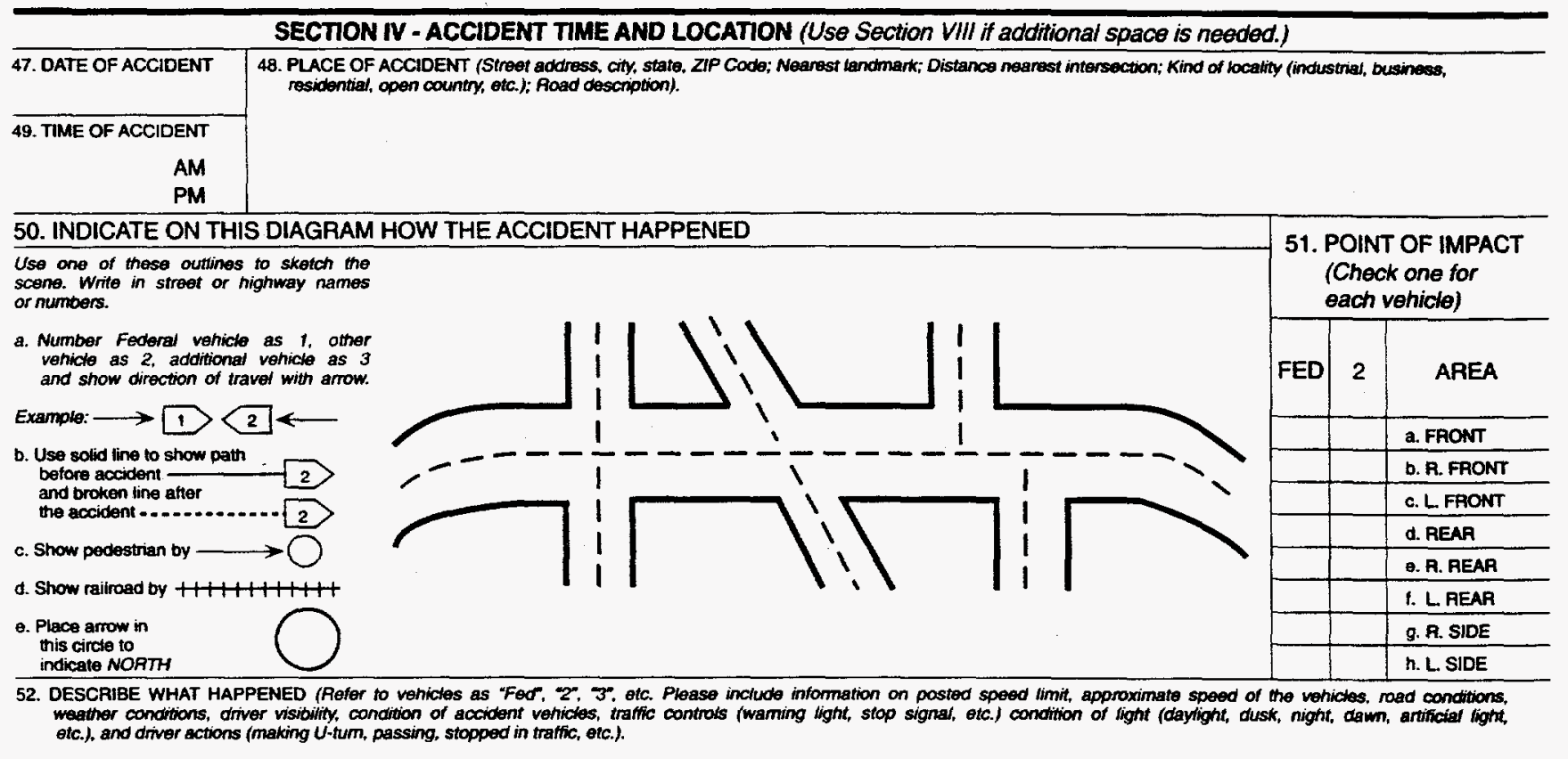

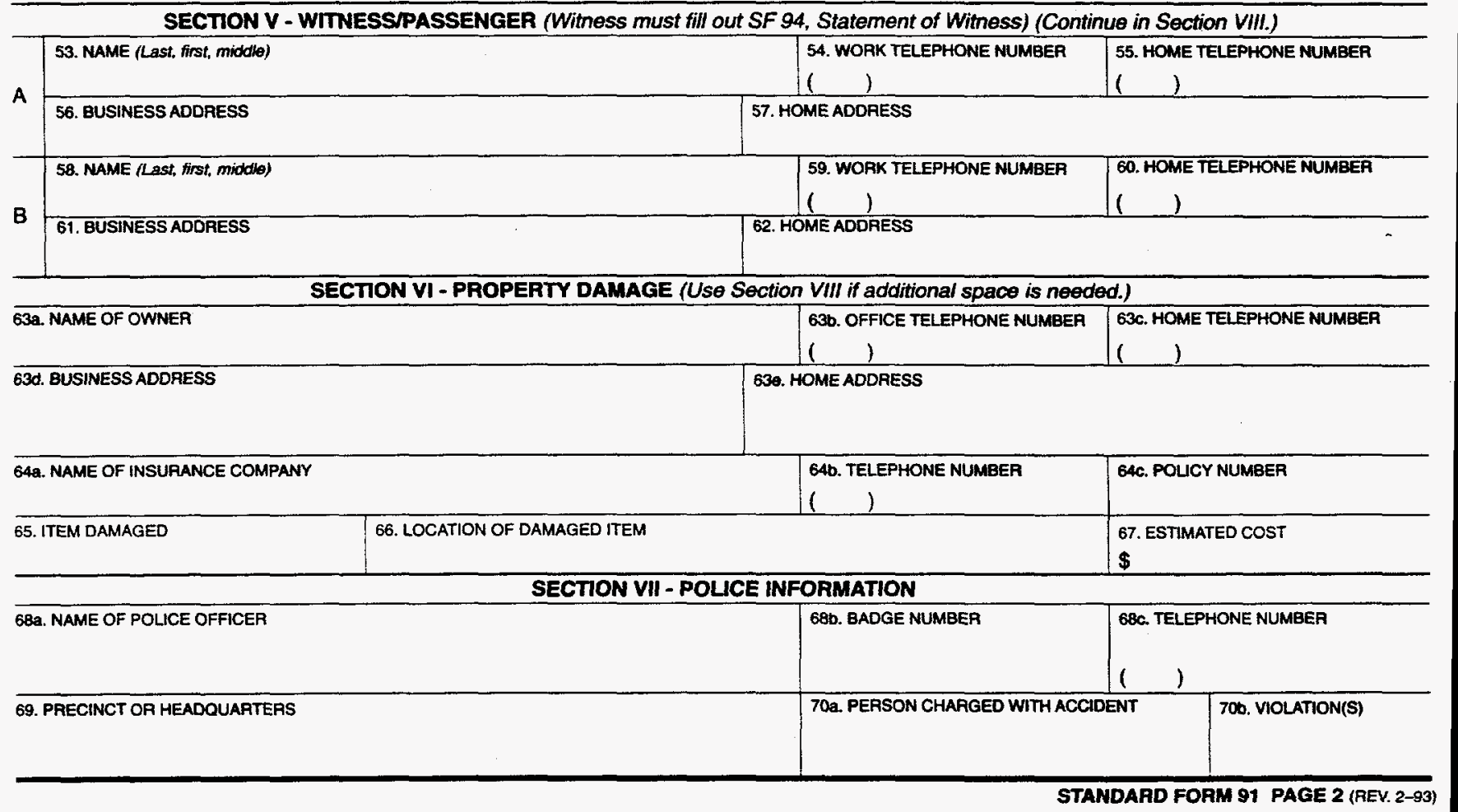


SECTION XI - ACCIDENT INVESTIGATION DATA

83. DID THE INVESTIGATION DISCLOSE CONFLICTING INFORMATION: $\square$ YES $\square$ NO (II 'Yes", explain below.)

84. PERSONS INTERVIEWED

\begin{tabular}{l|l|l|l|l|}
\hline \multicolumn{1}{|c|}{ NAME } & DATE & & \multicolumn{1}{c|}{ NAME } & DATE \\
\hline b. & & c. & \\
\hline & & d. & \\
\hline 85. ADDITIONAL COMMENTS (indicate section and item number for each comment) & & & \\
\hline
\end{tabular}

65. ADDITIONAL COMMENTS (Indicate section and inem number for each comment)

86. REVIEWING OFFICIAL'S COMMENTS

\begin{tabular}{|c|c|}
\hline 87. ACCIDENT INVESTIGATOR & 88. ACCIDENT REVIEWING OFFICIAL \\
\hline a. SIGNATURE AND DATE & a. SIGNATURE AND DATE \\
\hline b. NAME (First, middde, last) & b. NAME (First, middide, last) \\
\hline c. TITLE & c. TITLE \\
\hline d. OFFICE & d. OFFICE \\
\hline $\begin{array}{l}\text { e. OFFICE TELEPHONE NUMBEA } \\
(j)\end{array}$ & 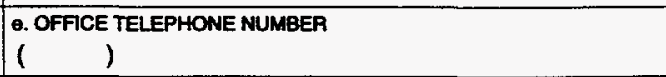 \\
\hline
\end{tabular}

ATT $1-5$ 


\section{ATTACHMENT 2}

Statement of Witness (Standard Form 94) 
CA0-96-1186

\begin{tabular}{|c|c|c|c|c|}
\hline \multirow{2}{*}{$\begin{array}{l}\text { STATEMENT OF WITNESS } \\
\text { (Attach additional sheets if necessary) }\end{array}$} & \multirow{2}{*}{$\begin{array}{l}\text { 1. OIO YOU SEE THE } \\
\text { ACCIDENT? }\end{array}$} & \multicolumn{2}{|c|}{ 2. WHEN DID THE ACCIOENT HAPPEN? } & \multirow{2}{*}{$\begin{array}{l}\text { FORM APPROVED } \\
\text { O.M.B. NUMBER } \\
3090-0118\end{array}$} \\
\hline & & a.m. & b. DATE & \\
\hline
\end{tabular}

3. WHERE DID THE ACCIDENT HAPPEN? (Give strezt location and city)

4. TELL IN YOUR OWN WAY HOW THE ACCIDENT HAPPENED

5. WHERE WERE YOU WHEN THE ACCIOENT OCGURRED?

6. WAS ANYONE INJURED. AND IF SO, EXTENT OF INJURY IF KNOWN?

7. DESCRIBE THE APPARENT DAMAGE TO PRIVATE PROPERTY

8. DESCRIBE THE APPARENT OAMAGE TO GOVERNMENT PROPERTY

9. IF TRAFFIC CASE, GIVE APPROX
SPEED OF:

a. GOVERNMENT VEHICLE

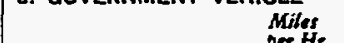

b. OTHFR VFHICLE

Der Hif.

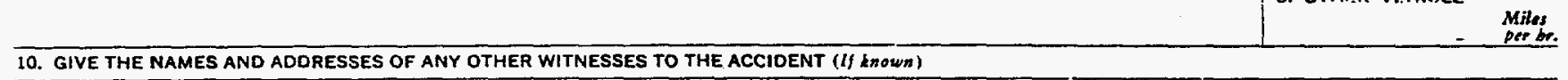

\begin{tabular}{|c|c|c|c|}
\hline \multicolumn{2}{|l|}{ a. NAMES } & \multicolumn{2}{|c|}{ b. ADDRESSES (Incinde ZIP Code) } \\
\hline \multirow{3}{*}{$\begin{array}{l}\text { WITNESS } \\
\text { COM. } \\
\text { PLETING } \\
\text { THIS } \\
\text { FORM }\end{array}$} & \multirow[t]{2}{*}{ 11. HOME ADDRESS (Include ZIP Code) } & 12. WITNESS (Print Name) & a. HOME TELEPHONE NO. \\
\hline & & $\begin{array}{c}\text { Sign } \\
\text { bere }\end{array}$ & b. TODAY'S DATE \\
\hline & \multicolumn{2}{|l|}{ 13. BUSINESS ADDRESS (Inciude ZIP Code) } & TELEPHONE NO. \\
\hline
\end{tabular}

14. INDICATE ON TME DIAGRAM BELOW WHAT HAPPENED:

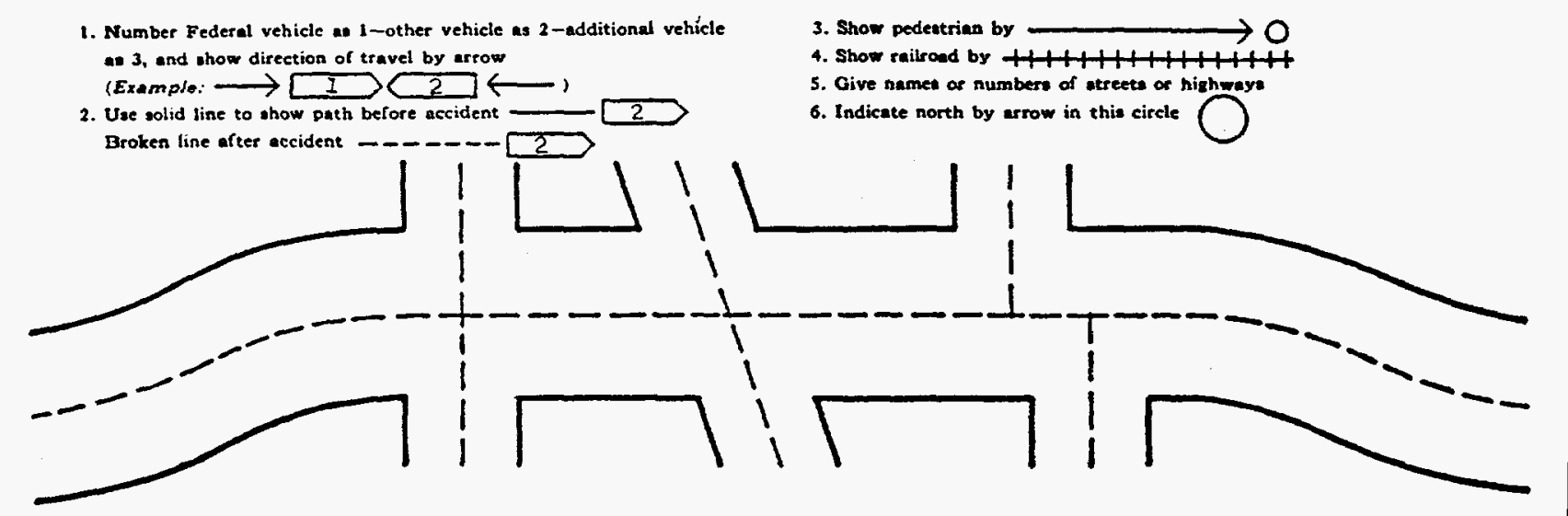


FILE REFERENCE:

This office has been notified that you witnessed an accident which occurred

It will be helpful if you will answer, as fully as possible, the questions on the other side of this letter. Please read the Privacy Act Statement below.

Your courtesy in complying with this request will be appreciated. An addressed envelope, which requires no postage, is enclosed for your convenience in replying.

Sincerely

Enclosure

Use by the public is voluntary. in compliance with the Privacy Act of 1974 , the following information is provided: Solicitation of the information requested on this form is authorized by Titie $40 \mathrm{U.S.C}$. Section 491 . Disclosure of the information by a Federal employee is mandatory as it is the first step in the Government's investigation of a motor vehicle accident. The principal purposes for which the information is intended to be used are to provide necessary data for use by legal counsel in legal actions resulting from the accident, and to provide accident information/statistics for use in analyzing accident causes and developing methods of reducing accidents. Routine use of the information may be by Federal, State or local governments or agencies, when relevant to civil, criminal, or regulatory investigations or prosecution.

it U.S.G.P.O.: $1993-342-199 / 50244$

STANDARD FORM 94 BACK (REV. 2-83)

ATT 2 - 2 